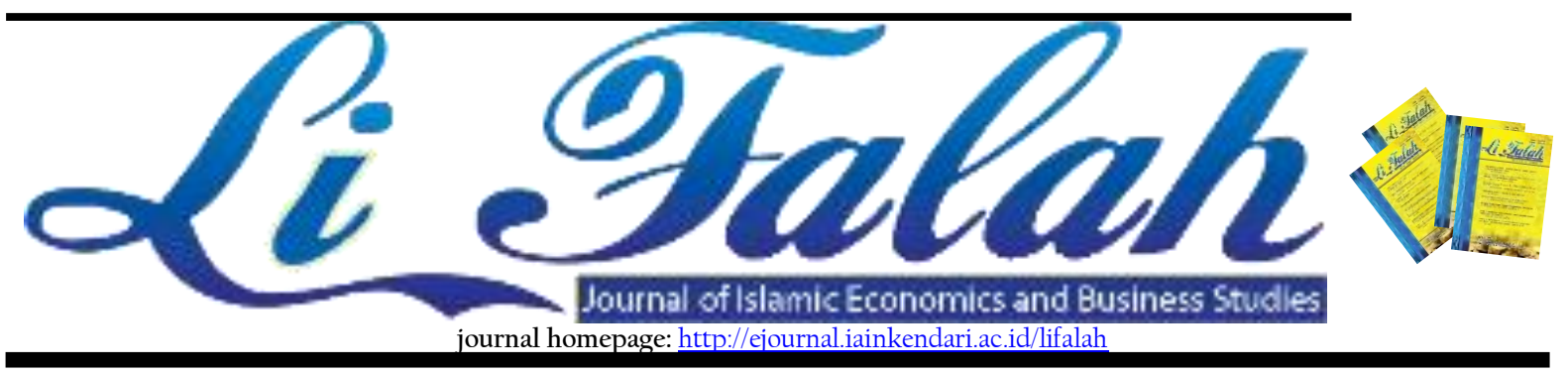

\title{
Religiosity and Halal Certification: Its Effect on Interest in Buying Traditional Food
}

\author{
Najmudin ${ }^{1}$, Syihabudin ${ }^{2}$, \\ 1,2, Universitas Sultan Ageng Tirtayasa, \\ e-cmail: *Inajmudin@untirta.ac.id, ${ }^{2}$ syihabudin@untirta.ac.id
}

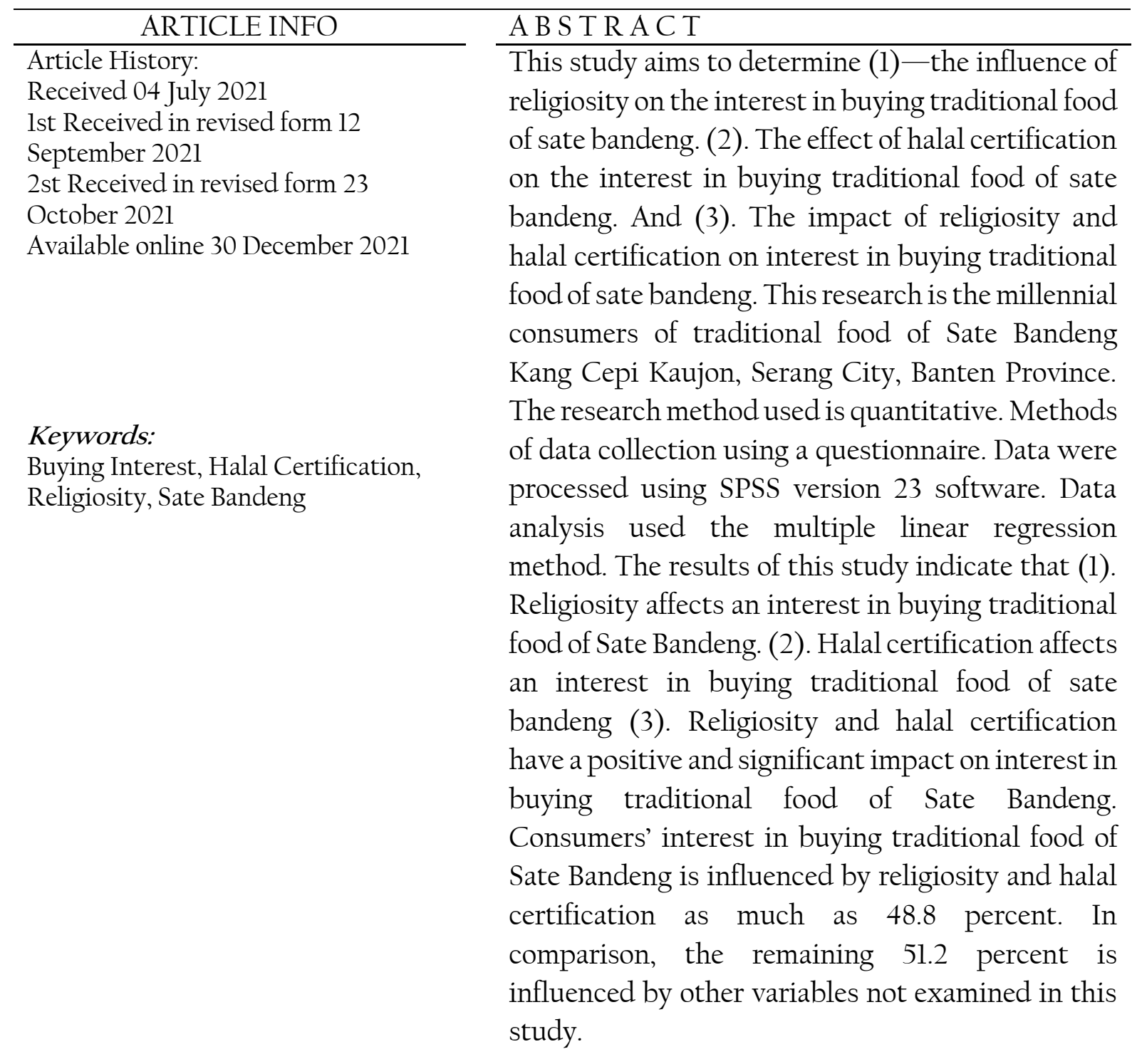




\section{Introduction}

Indonesia is a country that has a cultural diversity with different local wisdom. Of course, it is a characteristic of the Indonesian nation that is not owned by other countries. Likewise, each region has many culinary and different variations (Anam 2020). Food is part of a cultural product that characterizes the identity of a nation and a region. Food is created and developed by every human group or ethnic group. Food grown in their respective environments is traditional food (Intani T 2014). Food that is considered a form of a nation's identity does not rule out the possibility of experiencing a shift in values for existing humans. This fact is quite troubling, which can cause the loss of the identity of a nation. It can be seen from the phenomenon that many young people who prefer non-traditional food have participated in shifting the position of traditional food (Priscilla \& $\&$ Rizky, 2015).

This phenomenon is generally seen in the density of visitors to modern food outlets (foreign food franchises) in shopping centers that students and even families dominate. At the same time, traditional food outlets are starting to be abandoned because they have almost no appeal (Priscilla \& Rizky, 2015). This finding is also reinforced by the results of research conducted by Aviva, which states that the millennial generation or those who are currently 18 to 35 years old are willing to spend their money to buy pizza ten times a month. (Sari 2018). In line with that, the results of social observations from M. Sabran Achyar, Tanjungpura University, Pontianak, said that currently, there is less interest in traditional food among young people. Burhanuddin (2018) worried about traditional culinary in the future being less dominant with culinary from outside. This traditional cake seems to know only the elderly aged 50 years and over. The younger generation sometimes doesn't know it. The phenomenon of rapid technological development has contributed to marginalizing traditional foods to not compete with ethnic cuisines, such as pizza, hamburgers, fried chicken, and many more (Anam 2020).

Indonesia is a country with a majority Muslim population. According to data from the population census conducted by the Central Statistics Agency in 2010, as many as 207,176,162 or $87.17 \%$ of Indonesia's population are Muslim. Islam is a religion that guides Muslims in every aspect of life, not only in acts of fiqh worship (Alam, Mohd, and Hisham 2011) and acts of fiqh muamalah. Among the problems of fiqh, muamalah is choosing products for consumption. Products with religious elements, such as food, drinks, cosmetics, medicines, or even tourism, are the latest topics in the industrial world. The popular term halal food industry was achieved by the Indonesian state as the largest halal food producer in the world (Nofianti and Rofiqoh 2019). 
Increased awareness among Muslims of the need to consume halal food also plays a role in increasing the opportunities for the halal industry. With the growing global market in the halal industry, the opportunity to develop the halal industry in Indonesia is very high. Currently, the food industry in Indonesia makes a significant contribution. Based on data from the Central Statistics Agency (BPS), the manufacturing sector contributed $20.16 \%$ of Indonesia's total GDP, reaching Rp 13,588.8 trillion in 2017, with the highest growth in the food and beverage subsector going 13.76\%. (Suryaputri and Kurniawati 2020) In addition, religiosity affects consumer orientation regarding consumption patterns and social behavior, influences consumer choices, and is one of the main factors to promote a product (Rahman, Asrarhaghighi, and Rahman 2015).

Basri and Kurniawati (2019) say that religiosity significantly affects buying interest. Suryaputri and Kurniawati (2020) prove that religiosity partially affects buying halal products. Rahman et al. (2015) stated that religiosity affects buying interest in halal products in Indonesia. Lestari, Praktikto, and Hermawan (2020) show that religiosity significantly affects buying interest in cosmetics. Suryaputri and Kurniawati (2020) state halal certification significantly affects buying interest in halal products. Setyaningsih and Marwansyah (2019) show that halal certification positively affects buying interest in halal food products. Nofianti and Rofiqoh (2019) show that halal certification/halal logo positively affects buying interest in the products of MSMEs in the Gresik Regency.

The novelty of this study lies in the research object, namely the traditional food of state bandeng, and the respondents taken are millennials. This study tries to analyze further the relationship between millennial religiosity and halal certification attached to traditional milkfish satay food products with buying interest in food. The traditional food, which in the end proves how much millennials love the traditional food of their region.

\section{Literature Review}

\subsection{Halal Certification}

Experts have different views in defining halal certification/labeling. (Akhyar and Pramesti 2019) defines halal certification as a security guarantee for a Muslim consumer to choose good food for him and follow religious rules. Food products with halal certificates meet standards and are safe and clean in processing. While (Agustin H 2013) defines halal labeling as licensing the installation of the word Halal on product packaging from a company by the POM. (Fuad Z. Iwan 2010) explained that halal product certification is the process of licensing and inspecting food products to the authorized institution to issue halal product certificates. Meanwhile, according to (Andriansyah, Arifin, and S. 2019), Halal labeling is the process of 
applying for a permit to an authorized institution to issue a decision on granting a license to entrepreneurs to provide a halal label on their food product packaging. As food. Halal is related to halal assurance, as indicated by the existence of halal certification from LPPOM MUI. In addition to good food guarantees, the provision of halal guarantees will also increase the competitiveness of Indonesian local food products against imported products that do not get halal certification. Halal certification is focused on the raw materials included in the product and consists of the "Thoyyib" criteria, which are applied in every aspect of production. A halal certificate is a document issued by a Legal Religious Institution stating that the product complies with Islamic law and can be used by Muslims (Basri and Kurniawati 2019). According to (Andriansyah et al. 2019), Halal labeling indicators are (1) Halal labels are stamped on product packaging, (2) Halal compositions are listed on product packaging, (3) There is trust in product halalness.

\subsection{Religiosity}

Jalaludin (2010) states religiosity can be defined as a condition within the individual that encourages him to behave following the level of obedience to religion. According to (Wulandari 2021), religion is a factor that Muslims must own because religiosity is an identification that impacts all activities in his life. (Momtaz, Yahya, and Ibrahim 2011) State that religious action occurs when a person performs ritual behavior (worship) and other activities driven by supernatural powers. Not only concerning visible and visible actions and activities that do not seem to occur in the heart. People with higher levels of religiosity were significantly more likely to feel a greater connection to the universe than their counterparts with lower levels of Religiosity (Anggraini and Dewanti 2020). According to (Ma'zumi et al., 2017), religiosity can be measured by five indicators, namely (1) ideological belief, (2) religious practice, (3) religious experience, (4) religious knowledge, and (5) consequences.

\subsection{Buying interest}

According to (Mutmainah 2018), buying interest is consumers' tendency to buy something or take actions related to purchases and measure the level of probability of consumers making a purchase. According to (Anggraini and Dewanti 2020), buying interest is choosing one of two or more alternative options to buy a product. While (Nurcahyo and Hudrasyah 2017) view that buying stake is a consumer's tendency to buy something or make a purchase action that can be measured by the consumer's desire to make a purchase. Buying interest grows after consumers get a stimulus from the product they see, then there is a desire to try until finally there is a desire to buy and own a product (Puspita, Sunaryo, and Wijayanti 
2020). The consumer's intention or purpose determines purchase intention before making a transaction. Purchase intention can also be used as a basis for predicting consumer behavior. The process of making purchasing decisions for a product by consumers and customers is a simple definition of buying interest (Nofianti and Rofiqoh 2019). According to (Widyanto and Irfanur 2019), Indicators to measure buying stake are (1) the decision to buy, (2) recommend the product to others, (3) the desire to buy, and (4) satisfaction

\subsection{Framework}

The framework of this research is as follows:

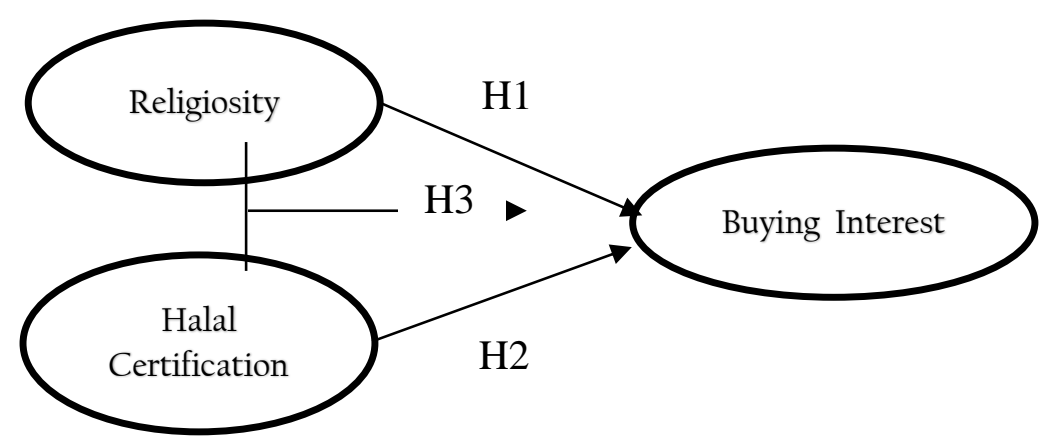

Chart 1. Framework of Thought

Sources: Rakhmawati (2018) and Wulandari (2021)

Based on the framework above, it can be seen that each religiosity and halal certification affects buying interest. Religiosity and halal certification simultaneously affect purchase interest.

\subsection{Hypothesis Development}

\subsubsection{Religiosity On Buying Interest}

Basri and Kurniawati (2019) show that religiosity significantly affects buying interest. Suryaputri and Kurniawati (2020) show that religiosity partially affects buying halal products. Rahman et al. (2015) stated that religiosity affects buying interest in halal products in Indonesia. Lestari et al. (2020) show that religiosity significantly affects buying interest in cosmetics. Lidiawati and Suryani (2020) show that religiosity significantly affects buying interest in Kober Mie Setan Gresik. Ibrahim and Ismail (2015) show that religiosity affects buying interest in non-food products labeled halal. Wulandari (2021) shows that religiosity affects purchasing decisions for Indomie in Sidoarjo. Rakhmawati (2018) shows that religiosity affects buying interest and purchasing decisions for Wardah cosmetics at Beauty House Surabaya. Akhyar and Pramesti (2019) show that religiosity significantly affects an 
interest in purchasing food at Japanese Food Restaurants. (Alam et al. 2011) shows Religiosity towards Wardah cosmetic buying interest in Yogyakarta. Based on the results of these studies, the hypotheses of this study are as follows. Religiosity has a positive effect on interest in buying traditional food of sate bandeng.

\subsubsection{Halal Certification On Buying Interest}

Suryaputri and Kurniawati (2020) show halal certification significantly affects buying interest in halal products. Research result(Setyaningsih and Marwansyah 2019)shows that halal certification positively affects buying interest in halal food products. Nofianti and Rofiqoh (2019) show that halal certification/halal logo positively affects buying interest in the products of MSMEs in the Gresik Regency. Nurcahyo and Hudrasyah (2017) state that halal certification has a significant positive effect on the welfare of students in the city of Bandung to buy instant noodles. Fatemeh Shabani (2016) says that halal certification has a significant positive impact on the interest of Muslims and non-Muslims in purchasing a product. (Aziz and Chok 2013) states that halal certification has a significant positive effect on the welfare of non-Muslims to buy halal products in Malaysia. Cloud et al. (2015) say that halal certification significantly impacts interest in buying halal food. (Zakaria et al. 2018) explained that halal certification particularly moved interest in halal products at Sabasun Hypermarket Sdn. Bhd. In Kuala Trengganu. Based on the research results above, the following hypotheses can be drawn: Halal certification affects an interest in buying traditional food of sate bandeng.

\subsubsection{Religiosity and Halal certification On buying interest}

Results of research conducted by Wulandari (2021) show that religiosity and halal certification have a simultaneous positive effect on Indomie purchasing decisions in Sidoarjo. Rakhmawati (2018) show that religiosity and halal certification simultaneously affect the buying interest of Wardah Cosmetics at Beauty House Surabaya. Based on the results of these studies, the following hypotheses can be drawn: Religiosity and halal certification simultaneously affect the interest in buying traditional food of sate bandeng. 


\section{Research Method}

The method used in this study is quantitative. According to (Arikunto 2010), Quantitative research is research whose data is expressed in the form of numbers or numbers that can be calculated systematically. The population is the entire research subject (Bachtiar 2018). The population in this study are consumers who have bought and consumed traditional Sate Bandeng food, the exact amount of which is not known. Determination of the number of samples in this study refers to (Ferdindand 2002) stating that the sample size depends on the number of indicators used in all variables. The number of samples equals the number of indicators multiplied by 5-10. So the number of samples in this study was set at 72 respondents, which was obtained from the total number of indicator variables used in this study, namely 12 , then multiplied by $6(12 \times 6=72)$.

The type of data used in this study is primary data. According to (Bungin 2015), primary data is collected directly from the source and processed by itself for use. The data collection method used is a questionnaire. A questionnaire by (Bungin 2015) is a questionnaire method or in the form of a series or collection of questions systematically arranged in a list of questions and then sent to the respondent to be filled out. Questionnaires were distributed to 72 millennial consumers of Sate Bandeng Kang Cepi Serang.

The data analysis method in this study is a quantitative descriptive approach. The analytical tool used is the SPSS version 23 program. The first test is the validity test used to measure validity. The reliability test where a questionnaire is said to be reliable or reliable if someone's answer to the statement is consistent or stable from time to time. The instrument is valid and reliable. The classical assumption test (normality, multicollinearity, and heteroscedasticity) is carried out. Multiple linear regression analysis is performed because this study has two independent variables. The hypothesis test consists of a t-test to partially see the independent variable's effect on the dependent variable-furthermore, the F test to see the effect of the independent variable on the dependent variable simultaneously. And the coefficient of determination test is used to determine the contribution of the independent variable in influencing the dependent variable (Ulya and Karneli 2018). 


\section{Result}

\subsection{Validity test}

The validity test was carried out using SPSS version 23 software. The results of the validity test of all items in the questionnaire can be seen in the following table:

\begin{tabular}{|c|c|c|c|}
\hline Question Items & $\begin{array}{l}\text { R-Value } \\
\text { Calculate }\end{array}$ & $\begin{array}{l}\text { RTable } \\
\text { Value }\end{array}$ & Conclusion \\
\hline \multicolumn{4}{|c|}{ Religiosity Variable } \\
\hline X1.1 & 0.677 & 0.235 & Valid \\
\hline $\mathrm{X} 1.2$ & 0.771 & 0.235 & Valid \\
\hline $\mathrm{Xl} .3$ & 0.799 & 0.235 & Valid \\
\hline $\mathrm{Xl} .4$ & 0.778 & 0.235 & Valid \\
\hline $\mathrm{X} 1.5$ & 0.624 & 0.235 & Valid \\
\hline \multicolumn{4}{|c|}{ Halal Certification Variable } \\
\hline X2.1 & 0.750 & 0.235 & Valid \\
\hline $\mathrm{X} 2.2$ & 0.857 & 0.235 & Valid \\
\hline $\mathrm{X} 2.3$ & 0.807 & 0.235 & Valid \\
\hline \multicolumn{4}{|c|}{ Buying Interest Variable } \\
\hline Y.1 & 0.698 & 0.235 & Valid \\
\hline Y.2 & 0.636 & 0.235 & Valid \\
\hline Y.3 & 0.740 & 0.235 & Valid \\
\hline Y.4 & 0.733 & 0.235 & Valid \\
\hline
\end{tabular}

Source. SPSS Data Processed 2021

Based on the results of the validity test in the table above, it is known that the $\mathrm{r}$ count value of all question items is greater than the r table (0.235), so it can be concluded that the question items in the questionnaire filled out by the respondents are all valid.

\subsection{Reliability Test}

The reliability test was carried out using SPSS version 23 software. The results of the Cronbach's Alpha reliability test for all questionnaire items can be seen in the following table:

Table 2. Reliability Test Results

\begin{tabular}{llll}
\hline Variable & $\begin{array}{l}\text { Cronbach's } \\
\text { Alpha value }\end{array}$ & $\begin{array}{l}\text { R-Value } \\
\text { Table }\end{array}$ & Conclusion \\
\hline Religiosity (X1) & 0.762 & 0.235 & Reliable \\
$\begin{array}{l}\text { Halal Certification } \\
\text { (X2) }\end{array}$ & 0.720 & 0.235 & Reliable \\
Buying Interest (Y) & 0.645 & 0.235 & Reliable \\
\hline
\end{tabular}

Source: SPSS Data Processed 2021 
Based on the results of the reliability test in the table above, it is known that the value of Cronbach's alpha of the religiosity variable $(\mathrm{Xl})$ is greater than the $\mathrm{t}$-table $(0.763>0.235)$, the value of Cronbach's alpha of the halal certification variable (X2) is more significant than t-table $(0.720>0.235)$. The value of Cronbach's alpha variable buying interest $(\mathrm{Y})$ is greater than the $t$-table $(0.645>0.235)$. Thus, it can be concluded that all variables in this study are reliable and reliable.

\subsection{Classic assumption test}

\subsubsection{Normality test}

The normality test was carried out using SPSS version 23 software. The results of the Kolmogorov Smirnov normality test can be seen in the following table:

Table 3 Normality Test Results

\begin{tabular}{|c|c|c|}
\hline \multicolumn{3}{|c|}{ One-Sample Kolmogorov-Smirnov Test } \\
\hline & & $\begin{array}{c}\text { Unstandardiz } \\
\text { ed Residual }\end{array}$ \\
\hline $\mathrm{N}$ & & 72 \\
\hline \multirow[t]{2}{*}{ Normal Parameters, b } & mean & .0000000 \\
\hline & $\begin{array}{l}\text { Std. } \\
\text { Deviation }\end{array}$ & 1.96988375 \\
\hline Most Extreme & Absolute & .096 \\
\hline \multirow[t]{2}{*}{ Differences } & Positive & .077 \\
\hline & negative & -.096 \\
\hline Test Statistics & & .096 \\
\hline asymp. Sig. (2-tailed) & & $.097 c$ \\
\hline $\begin{array}{l}\text { a. Test distribution is I } \\
\text { b. Calculated from dat } \\
\text { c. Lilliefors Significanc }\end{array}$ & $\begin{array}{l}\text { rmal. } \\
\text { Correction. }\end{array}$ & \\
\hline
\end{tabular}

Source. SPSS Data Processed, 2021

Based on the results of the normality test in the table above. It is known that the significance value of the Kolmogorov Smirnov test is greater than the alpha value (0.097>0.05), so it can be said that the residual model data is normally distributed or the assumption of normality has been met. 


\subsubsection{Multicollinearity Test}

A multicollinearity test was carried out using SPSS version 23 software. The results of the multicollinearity test can be seen in the following table:

Table 4. Multicollinearity Test Results

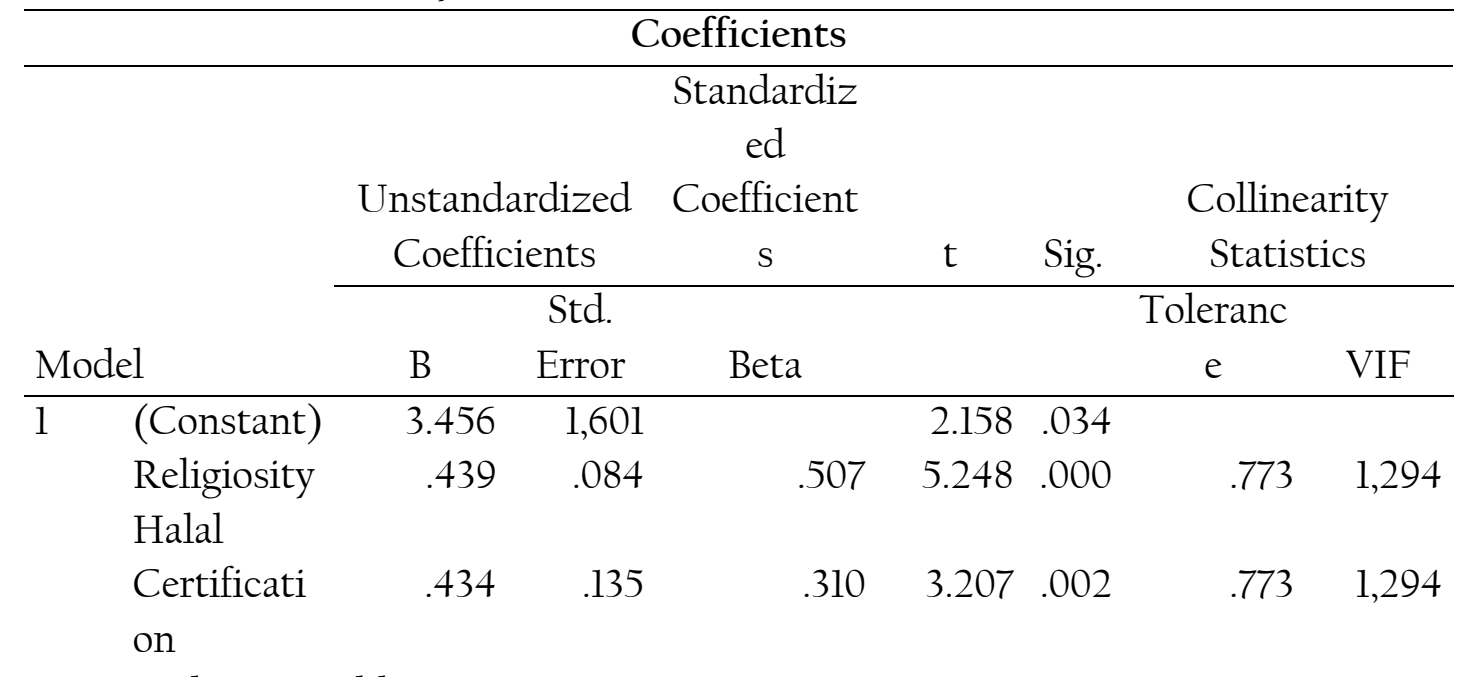

a. Dependent Variable: Buying interest

Source. SPSS Data Processed, 2021

The table above shows that the religiosity and halal certification variables have a tolerance value greater than 0.10 (0.773 > 0.10). And a VIF value less than $10(1,294<10)$, it can be concluded that the data is free from multicollinearity symptoms.

\subsubsection{Heteroscedasticity Test}

A heteroscedasticity test was carried out using SPSS version 23 software. The results of the heteroscedasticity test can be seen in the following table:

Table 5. Heteroscedasticity Test Results

\begin{tabular}{|c|c|c|c|c|c|c|}
\hline \multicolumn{7}{|c|}{ Coefficients } \\
\hline \multirow[b]{2}{*}{ Model } & & \multicolumn{2}{|c|}{$\begin{array}{c}\text { Unstandardized } \\
\text { Coefficients }\end{array}$} & $\begin{array}{l}\text { Standardized } \\
\text { Coefficients }\end{array}$ & \multirow[b]{2}{*}{$t$} & \multirow[b]{2}{*}{ Sig. } \\
\hline & & B & Std. Error & Beta & & \\
\hline 1 & (Constant) & 1.618 & 1.419 & & 1,140 & .258 \\
\hline & Religiosity & -.008 & .055 & -.017 & -140 & .889 \\
\hline & $\begin{array}{l}\text { Halal } \\
\text { Certification }\end{array}$ & .018 & .075 & .030 & .245 & .807 \\
\hline
\end{tabular}

a. Dependent Variable: RES2

Source: SPSS Data Processed 2021 
The table above shows that the significance value of the religiosity variable is greater than the alpha value $(0.889>0.05)$. And the significance value of the halal certification variable is greater than the alpha value $(0.809>0.05)$, so it can be concluded that there is no heteroscedasticity in the regression model in this study.

\subsection{Correlation Coefficient Test}

The correlation coefficient test was carried out using SPSS version 23 software. The results of the correlation coefficient test can be seen in the following table:

Table 6. Correlation Coefficient Test

\begin{tabular}{lcccr}
\hline \multicolumn{4}{c}{ Model Summary } \\
\hline Model & $\mathrm{R}$ & R Square & $\begin{array}{c}\text { Adjusted R } \\
\text { Square }\end{array}$ & $\begin{array}{c}\text { Std. Error of } \\
\text { the Estimate }\end{array}$ \\
\hline l & $.709 \mathrm{a}$ & .503 & .488 & 1.69525 \\
a. Predictors: (Constant), Halal Certification, Religiosity \\
\hline \multicolumn{2}{l}{ Source. SPSS Data Processed, 2021 }
\end{tabular}

The test results table above shows that the correlation coefficient of religiosity and halal certification variables on the interest in buying traditional food of sate bandeng is 0.488 . This value indicates that consumers' buying interest in traditional milkfish satay by religiosity and halal certification is 48.8 percent. At the same time, the remaining 51.2 is influenced by other variables not examined in this study.

\subsection{Hypothesis testing}

\subsubsection{F Test}

The calculated F test was carried out using SPSS version 23 software. The results of the Count $\mathrm{F}$ test can be seen in the following table:

Table 7. F Test Results Calculate

\begin{tabular}{|c|c|c|c|c|c|c|}
\hline \multicolumn{7}{|c|}{ ANOVA } \\
\hline Model & & $\begin{array}{l}\text { Sum of } \\
\text { Squares }\end{array}$ & df & Mean Square & $\mathrm{F}$ & Sig. \\
\hline \multirow[t]{3}{*}{1} & Regression & 200.313 & 2 & 100.157 & 34,851 & $.000 \mathrm{~b}$ \\
\hline & Residual & 198,298 & 69 & 2.874 & & \\
\hline & Total & 398,611 & 71 & & & \\
\hline
\end{tabular}

a. Dependent Variable: Buying interest

b. Predictors: (Constant), Halal Certification, Religiosity

Source. SPSS Data Processed, 2021 
Based on the statistical F test results above, it is known that the F value of the religiosity and halal certification variables is 34,851 , and the significance value is 0.000 . while the F-table value is 3.20 and the alpha value is 0.05 . when compared, the value of the F-count is greater than Ftable $(34,851>3.20)$, and the significance value is less than the value of alpha $(0.000<$ 0.05). Thus, religiosity and halal certification simultaneously have a positive and significant effect on buying traditional food of sate bandeng.

\subsubsection{T-test}

The t-test for each variable of religiosity and halal certification on buying interest was carried out using SPSS version 23 software. The results of the t-test can be seen in the following table:

Table 8. t-test results Calculate

\begin{tabular}{|c|c|c|c|c|c|c|}
\hline \multicolumn{7}{|c|}{ Coefficients } \\
\hline \multirow[b]{2}{*}{ Model } & & \multicolumn{2}{|c|}{$\begin{array}{c}\text { Unstandardized } \\
\text { Coefficients }\end{array}$} & $\begin{array}{l}\text { Standardized } \\
\text { Coefficients }\end{array}$ & \multirow[b]{2}{*}{$t$} & \multirow[b]{2}{*}{ Sig. } \\
\hline & & $\mathrm{B}$ & Std. Error & Beta & & \\
\hline \multirow[t]{2}{*}{1} & (Constant) & 6,952 & 1,248 & & 5.570 & .000 \\
\hline & Religiosity & .567 & .078 & .655 & 7.243 & .000 \\
\hline \multicolumn{7}{|c|}{ a. Dependent Variable: Buying Interest } \\
\hline
\end{tabular}

Based on the results of the statistical $t$-test in the table above. It is known that the $t$ count value of the religiosity variable is 7.243 , and the significance value is 0.000 . While the $t$ table of the religiosity variable is 1.669 , and the alpha value is 0.05 . when compared, the $t$-count value is greater than the $t$-table $(7,243>1.669)$ and the significance value is smaller than the alpha value $(0.000<0.05)$. Thus, religiosity has a positive and significant effect on interest in buying traditional food of sate bandeng.

Table 9. t-test results Calculate

\begin{tabular}{|c|c|c|c|c|c|c|}
\hline \multicolumn{7}{|c|}{ Coefficients } \\
\hline \multirow[b]{2}{*}{ Model } & & \multicolumn{2}{|c|}{$\begin{array}{l}\text { Unstandardized } \\
\text { Coefficients }\end{array}$} & $\begin{array}{l}\text { Standardized } \\
\text { Coefficients }\end{array}$ & \multirow[b]{2}{*}{$t$} & \multirow[b]{2}{*}{ Sig. } \\
\hline & & B & Std. Error & Beta & & \\
\hline 1 & (Constant) & 6.060 & 1,788 & & 3.389 & .001 \\
\hline & $\begin{array}{l}\text { Halal } \\
\text { Certification }\end{array}$ & .772 & .140 & .551 & 5.529 & .000 \\
\hline a. Depe & ndent Variable & g Interest & & & & \\
\hline
\end{tabular}


Based on the results of the statistical $t$-test in the table above, it is known that the $t$ count value of the halal certification variable is 5.529, and the significance value is 0.000 , while the $t$-table value of the halal awareness variable is 1.669 and the alpha value is 0.05 . when compared, the $t$-count value is greater than the $t$-table $(5.529>1.669)$, and the significance value is smaller than the alpha value $(0.000<0.05)$. Thus, the halal certification has a positive and significant effect on interest in buying traditional food of sate bandeng.

\section{Discussion}

\subsection{Religiosity On Interest in Buying Traditional Food Of Sate Bandeng}

Religiosity is a condition that exists within the individual that encourages him to behave following the level of obedience to religion (Jalaludin 2010). Based on the results of the research above, it is known that the $t$-count value of the religiosity variable is greater than the t-table $(7,243>1.669)$, and the significance value is smaller than the alpha value $(0.000<0.05)$. Thus, religiosity has a positive and significant effect on buying interest in traditional milkfish satay. This study indicates that the better the level of consumer religiosity, the higher their buying interest in traditional milkfish satay. the value of religiosity that affects consumers, namely ideology, practice/appreciation, knowledge, consequences, and knowledge (Wulandari 2021)

This study follows the study results (Basri and Kurniawati 2019), which shows that religiosity significantly affects buying interest. Suryaputri and Kurniawati (2020) show that religiosity partially affects buying halal products. Rahman et al. (2015) stated that religiosity affects buying interest in halal products in Indonesia. Lestari et al. (2020) show that religiosity significantly affects buying interest in cosmetics. Lidiawati and Suryani (2020) show that religiosity significantly affects buying interest in Kober Mie Setan Gresik. Ibrahim and Ismail (2015) show that religiosity affects buying interest in non-food products labeled halal. Wulandari (2021) shows that religiosity affects purchasing decisions for Indomie in Sidoarjo. Rakhmawati (2018) shows that religiosity affects buying interest and purchasing decisions for Wardah cosmetics at Beauty House Surabaya. Akhyar and Pramesti (2019) show that religiosity significantly affects an interest in buying food at Japanese Food Restaurants. Alam et al. (2011) show Religiosity towards Wardah cosmetic buying interest in Yogyakarta.

\subsection{Halal Certification On Interest in Buying Traditional Food of Sate Bandeng}

Halal certification is a security guarantee for a Muslim consumer to choose good food for him and follow religious rules. Food products with a halal certificate meet safety and cleanliness standards (Akhyar and Pramesti 2019). Based on the statistical t-test on the 
research results above, it is known that the $t$-table value of the halal awareness variable is 1.669 , and the alpha value is 0.05 . when compared, the $t$-count value is greater than the $t$-table (5.529 > 1.669), and the significance value is smaller than the alpha value $(0.000<0.05)$. Thus, the halal certification has a positive and significant effect on buying interest in traditional milkfish satay. These results indicate that the more traditional foods are certified as halal by the Indonesian Ulema Council (MUI), the more interested people are in buying traditional foods. Halal certification in question is the existence of a halal label on product packaging, available halal composition on product packaging, trust in halal products (Andriansyah et al. 2019)

This study follows the results (Suryaputri and Kurniawati 2020), showing that halal certification significantly affects buying interest in halal products. Setyaningsih and Marwansyah (2019) show that halal certification positively affects buying interest in halal food products. Nofianti and Rofiqoh (2019) show that halal certification/halal logo positively affects buying interest in MSME products in Gresik Regency. Nurcahyo and Hudrasyah (2017) state that halal certification has a significant positive effect on students' interest in the city of Bandung to buy instant noodles. (Fatemeh Shabani 2016) states that halal certification has a significant positive effect on the interest of Muslims and non-Muslims in purchasing a product. Aziz and Chok (2013) state that halal certification has a significant positive effect on the interest of non-Muslims to buy halal products in Malaysia. Cloud et al. (2015) state that halal certification significantly affects an interest in buying halal food. Zakaria et al. (2018) explained that halal certification significantly affected interest in halal products at Sabasun Hypermarket Sdn. Bhd. In Kuala Trengganu

\subsection{Religiosity and Halal Certification on Interest in Buying Traditional Food Of Sate}

\section{Bandeng}

Based on the results of the statistical $F$ test above, it is known that the calculated $F$ value is greater than the F table $(34,851>3.20)$, and the significance value is smaller than the alpha value $(0.000<0.05)$. Thus, religiosity and halal certification simultaneously have a positive and significant effect on buying traditional food of sate bandeng. At the same time, the correlation coefficient of religiosity and halal certification variables on the interest in buying traditional sate bandeng is 0.488 . This value indicates that consumers' interest in buying traditional sate bandeng by religiosity and halal certification is 48.8 percent. In comparison, the remaining 51.2 percent is influenced by other variables not examined in this study.

This study follows the research results (Wulandari 2021), which shows that religiosity and halal certification simultaneously positively affect Indomie purchasing decisions in 
Sidoarjo. Research result (Rakhmawati 2018) show that religiosity and halal certification simultaneously affect the buying interest of Wardah Cosmetics at Beauty House Surabaya.

\section{Conclusion}

Based on the results of the research and discussion above. It can be concluded that religiosity has a positive and significant effect on interest in buying traditional food of sate bandeng. The halal certification has a positive and significant impact on interest in buying traditional food of sate bandeng, and religiosity and halal certification simultaneously have a positive and significant effect. Significantly to the interest in buying conventional sate food bandeng. Thus, the better the level of consumer religiosity coupled with the availability of halal certification for conventional food products, the more interest in buying conventional sate food bandeng will increase. At the same time, the correlation coefficient of religiosity and halal certification variables on the good in buying traditional food of sate bandeng is 0.488 . it means that consumers' interest in buying traditional Sate Bandeng is influenced by religiosity and halal certification as much as 48.8 percent. In comparison, the remaining 51.2 percent is influenced by other variables not examined in this study. 
Najmudin e Syihabudin/Li Falah-Jurnal Studi Ekonomi dan Bisnis Islam, Volume 6 (No.2 2021)

\section{References}

Akhyar, Kemal Faza, and Diesyana Ajeng Pramesti. 2019. "Pengaruh Religiusitas Dan Sertifikasi Halal Terhadap Keputusan Pembelian (Studi Empiris Pada Japanese Food Restaurant Di Magelang).” Jurnal Analisis Bisnis Ekonomi 13(2):617.

Alam, Syed Syah, Rohani Mohd, and Badrul Hisham. 2011. "Is Religiosity an Important Determinant on Muslim Consumer Behaviour in Malaysia?" Journal of Islamic Marketing 2(1):2011.

Anam, Samsul. 2020. “6 Jajanan Tradisional Khas Indonesia Ini Jarang Dijumpai.” Www.brilio.net.

Andriansyah, Yusuf, Rois Arifin, and Afi Rachmat S. 2019. "Analisis Pengaruh Label Halal Terhadap Keputusan Pembelian Makanan Impor Dalam Kemasan Pada Mahasiswa Kedokteran Universitas Sumatera Utara." Journal of Chemical Information and Modeling 53(9):1689-99.

Anggraini, Inar, and Diah Setyawati Dewanti. 2020. "The Effect of Halal Foods Awareness on

Purchase Decision with Religiosity as a Moderating Variable." Journal of Economics Research and Social Sciences 4(1). doi: 10.18196/jerss.040116.

Arikunto. 2010. Prosedur Penelitian: Suatu Pendekatan Praktik. Edisi Revi. Jakarta: Rineka Cipta. Awan, Hayat M., Ahmad Nabeel Siddiquei, and Zeeshan Haider. 2015. "Factors Affecting Halal Purchase Intention - Evidence from Pakistan's Halal Food Sector." Management Research Review 38(6):640-60. doi: 10.1108/mrr-01-2014-0022.

Aziz, Yuhanis Abdul, and Nyen Vui Chok. 2013. "The Role of Halal Awareness, Halal Certification, and Marketing Components in Determining Halal Purchase Intention Among Non-Muslims in Malaysia: A Structural Equation Modeling Approach." Journal of International Food and Agribusiness Marketing 25(1):1-23. doi: 10.1080/08974438.2013.723997. Bachtiar, Danis Imam. 2018. “Analisis Pengaruh Diversifikasi Produk Dan Harga Terhadap Keputusan Pembelian Pada UKM Gula Kelapa." Jurnal Ekonomi Dan Bisnis 52-60.

Basri, Yuswar Zainul, and Fitri Kurniawati. 2019. "Effect of Religiosity and Halal Awareness on Purchase Intention Moderated by Halal Certification." KnE Social Sciences 2019:592607. doi: 10.18502/kss.v3i26.5403.

Bungin, S. 2015. Metodologi Penelitian Sosial Dan Ekonomi. Volume 2. Jakarta: Kencana. Burhanuddin, Nur Hasni. 2018. "Strategi Pemasaran Makanan Khas Tradisional Di Kecamatan Wotu." Journal of Islamic Management and Bussines 1(2):20-32.

Fatemeh Shabani, Ghadikolaei. 2016. "The Effect of Halal Signs and Symptoms and Consumers' Purchase Intention in Muslim and Non-Muslim Countries - A Review." 
International Journal of Busines and Management Invention 5(7):44-49.

Fuad Z. Iwan, SH. 2010. “Kesadaran Hukum Pengusaha Kecil Bidang Padangan Dalam

Kemasan Di Kota Semarang Terhadap Regulasi Sertifikasi Produk Halal.” Universitas Diponegoro.

H, Eri Agustian. 2013. "Pengaruh Labelisasi Halal Terhadap Keputusan Pembelian Konsumen Studi Kasus Pada Produk Wall's Conello." Jurnal Ilmiah Manajemen Kesatuan 1(2):169-78. Ibrahim, Hifza, and Hashanah Ismail. 2015. "A Generational Cohort Study of the Relationship between Religious Intensity and Religious Assurance for the Purchase of Non-Food Products." International Journal of Economics and Financial Issues 5(2):330-34. Intani T, Ria. 2014. "Kiat Penjual Makanan Tradisional Dalam Menembus Pasar.” Patanjala : Jurnal Penelitian Sejarah Dan Budaya 6(2):315. doi: 10.30959/patanjala.v6i2.202. Jalaludin. 2010. Psikologi Agama. Jakarta: Rajawali Press.

Lestari, Ayu, Heri Praktikto, and Agus Hermawan. 2020. "The Effect Of Religiosity On The Purchase Intention Halal Cosmetics Through Attitude (Studies On Muslim Several Universities In Malang Indonesia)." Journal of Chemical Information and Modeling 22(1):20311.

Lidiawati, Veny, and Tatik Suryani. 2020. "Understanding The Influence of Ingredients, Halal Logo and Religiosity on the Consumer Purchase Intention at Kober Mie Setan Gresik." International Journal of Multicultural and Multireligious 294-307.

Ma’zumi, Taswiyah, and Najmudin. 2017. "Pengaruh Religiusitas Terhadap Perilaku Ekonomi Masyarakat Pasar Tradisional.” Al-Qalam: Jurnal Kajian Islam 34(2):277-300. Momtaz, Y. A., N. Yahya, and R. Ibrahim. 2011. "Moderating Effect of Religiosity in the Relationship between Social Isolation and Psychological Well-Being." Mental Health, Religion, \& Culture 14(2):141-56. doi: https://doi.org/10.1080/13674676.2010.497963. Mutmainah, Lu'liyatul. 2018. "The Role of Religiosity, Halal Awareness, Halal Certification, and Food Ingredients on Purchase Intention of Halal Food." Ihtifaz: Journal of Islamic Economics, Finance, and Banking 1(1):33. doi: 10.12928/ijiefb.vlil.284.

Nofianti, Kholis Amalia, and Siti Nur Indah Rofiqoh. 2019. "Kesadaran Halal Dan Logo Halal: Apakah Menentukan Minat Beli? (Studi Pada Pelaku Bisnis UMKM Di Gresik).” Journal of Halal Product and Research 2(1):16-24. doi: 10.20473/jhpr.vol.2-issue.2.51-59.

Nurcahyo, Agung, and Herry Hudrasyah. 2017. "The Influence of Halal Awareness, Halal Certification, and Personal Societal Purchase Intention." Journal of Business and Management 6(1):21-31.

Priskila, Brahmana Adiasih, and K. M. R. Rizky. 2015. “Persepsi Terhadap Makanan 
Tradisional Jawa Timu: Studi Awal Terhadap Mahasiswa Perguruan Tinggi Swasta Di Surabaya." Kinerja 19(2):112-25.

Puspita, Wanda A., Sunaryo, and Risna Wijayanti. 2020. "The Effects between Religious Belief, Halal Logo, and Halal Product Knowledge on Purchase Intention Mediated by Halal Awareness (Study on Consumers Of Beverage Franchise Products In Malang)." South-East Asia Journal of Contemporary Business, Economics and Law 21(5):306-19. Rahman, Azmawani Abd, Ebrahim Asrarhaghighi, and Suhaimi Ab Rahman. 2015.

"Consumers and Halal Cosmetic Products: Knowledge, Religiosity, Attitude and Intention." Journal of Islamic Marketing 6(1):148-63. doi: 10.29244/jam.8.1.57-72. Rakhmawati, Antin. 2018. "Pengaruh Label Halal Dan Religiusitas Terhadap Minat Beli Dan Keputusan Pembelian (Studi Pada Wardah Beauty House Surabaya).” Jurnal Sketsa Bisnis $5(1): 48-59$.

Sari, Fitriana Monica. 2018. "Studi: Milenial Penggila Makanan Cepat Saji, Benarkah ?" liputan6.com.

Setyaningsih, Eka Dyah, and Sofyan Marwansyah. 2019. "The Effect of Halal Certification and Halal Awareness through Interest in Decisions on Buying Halal Food Products.” Syi ar Iqtishadi : Journal of Islamic Economics, Finance and Banking 3(1):65. doi:

10.35448/jiec.v3il.5515.

Suryaputri, Rossje V., and Fitri Kurniawati. 2020. “Analisis Faktor-Faktor Yang

Mempengaruhi Niat Beli Produk Halal.” Taraadin 1(1):1-15.

Ulya, Ade Nurul, and Okta Karneli. 2018. "Pengaruh Diversifikasi Dan Kualitas Produk Terhadap Kepuasan Pelanggan Pada Toko Rabbani Cabang Pekanbar." JOM FISIP 5(Edisi II Juli - Desember):1-14.

Widyanto, Hanif Adinugroho, and Muhammad Khalil Irfanur. 2019. "Faith-Based Marketing: Antecedents of Purchase Intention for Halal-Certified Personal Care Products." Jurnal Muara Ilmu Ekonomi Dan Bisnis 3(2):421. doi: 10.24912/jmieb.v3i2.7338.

Wulandari, Sri. 2021. "Pengaruh Label Halal Dan Religiusitas Terhadap Keputusan Pembelian (Studi Kasus Konsumen Indomie Di Sidoarjo).” Jurnal Riset Manajemen Dan Bisnis Dewantara 4(1):4l.

Zakaria, Z., M. D. Abdul Majid, Z. Ahmad, Z. Jusoh, and N. Z. Zakaria. 2018. "Influence of Halal Certification on Customers' Purchase Intention." Journal of Fundamental and Applied Sciences 9(5S):772-87. doi: 10.4314/jfas.v9i5s.55. 